\title{
Tradition and Fortune: The Anthropology of Javanese Marriage
}

\author{
$1^{\text {st }}$ Kholis Bidayati $^{1}, 2^{\text {nd }}$ J.M. Muslimin ${ }^{1}, 3^{\text {rd }}$ Imam Subchi $^{2}, 4^{\text {th }}$ Saifudin Asrori $^{3}$ \\ \{kholis_bidayati19@mhs.uinjkt.ac.id ${ }^{1}$,jm.muslimin@uinjkt.ac.id ${ }^{1}$, imam.subchi@uinjkt.ac.id² \\ UIN Syarif Hidayatullah, Islamic Studies Department, Jakarta, Indonesia ${ }^{1}$, UIN Syarif Hidayatullah, \\ Historical and Antrhropology Department, Jakarta, Indonesia ${ }^{2}$, UIN Syarif Hidayatullah, Social and \\ Politics Studies Department, Jakarta, Indonesia ${ }^{3}$
}

\begin{abstract}
The study aims to analyze the interaction of Islamic family law and customary law in Java's Muslim society. The method used a field research method. The approach used in conducting the problem of this research is the anthropology. Java has many cultures, especially in the field of marriage, one of them pepali nikah. It is uncommon for the culture to sometime be mystical and as though contrary to Islamic law and much research stoped in conclusion if there is customary law to be in contradiction with Islamic law than customary law should leave out. Therefore as soon as possible customary law will eliminate from its position. The result of the research shows that there is harmonization of Islamic and customary law. There are some Islamic values in this tradition. Both of them have the same goal of forming a sakinah, mawaddah, and rahmah family though in different ways.
\end{abstract}

Keywords: Islamic law, customary law, family law, marriage, Java.

\section{Intrudoction}

The culture is creat by people, and they are always in the process. It happens because the culture is an integration, then what is meant is that elements or traits that are integrated into a culture are not a collection of habits that are collected in a mess.[1] Javanese is one of the many tribes in Indonesia have a wealth and diversity of traditions, customs, and culture, ranging from language to religion. One of them is pepali culture.

Pepali is the embodiment of values seen in every action or behavior of the members of the community, needs to be upheld for the rhythm of life following the power of nature and the noble ideals of the community or nation.[2] While pepali of marriage is a values in a marriage tradition in Java, one of them prohibition on marriage within a certain time and certain conditions.

A deep belief in pepali nikah (marriage pepali) made the Javanese people careful in finding a mate. They would rather cancel an arranged marriage than break pepali. According to them carrying out pepali aims to maintain the permanence of marriage. Besides that, violating pepali also causes sanctions around the community, like gossip or public scorn. But, in Islam, the marriage procession does not recognize this. Also, Islamic law stipulates that men are not free to choose women to be wives. There are standard provisions about women who can be married and those who are not. The woman who can be married is a woman who is not a mahram of the man concerned.

While illegitimate women who are married are classified into two, namely forbidden temporarily (mahram ghoiru muabbad), such as marrying two women who are siblings at 
once, and illegitimate forever (mahram muabbad), as due to blood relations. The most important requisites of a valid marriage relating to "Contracting Parties". The "Contracting Parties" would not be within the prohibited degrees to marriage. In a clear word if Contracting Parties of a marriage within the prohibited degree to marriage, such marriage turns into illegal or void.[3]

According to Soerjono Soekanto, the relationship between Islamic and customary law can be approached with a sociological approach that will produce a more natural representation. Both of Islamic and customary law are seen as inter-legal subsystems having an equal position in society.[4]

The implementation of Islamic law in Indonesia is divided into two stages. First, during the Dutch colonial period and second, during the reign of the Republik Indonesia. In the Dutch colonial period put Islamic law on two situations and in two periods, namely the acceptance it in full (Receptie in Complexu), and acceptance it over customary law (Receptie). While the reign of the Republic of Indonesia also placed Islamic law on two conditions in two periods, that is accepted as the persuasive source and authoritative source.[5] There appears to be a contradiction between Islamic law and customary law in Java. because customary law has different rule those Islamic laws.

Basically, Indonesian Muslims are not monolithic. Plurality exists in various traditions, understandings, and religious practices as an expression of belief in Islam. People develop tradition, simplicity, and customs to serve the interests of their religion and to spread religion; to understand and feel moral and noble values.

Indonesia is a country known as plurality which is composed of ethnicity, culture, language, and customs. According to Mat Syuroh, Indonesian people follow several religions and many traditional beliefs are found in rural areas. These traditional beliefs are then often bred with animistic beliefs. Since Islam entered Java, around the 14th century, the Java society can accept it well. But to illustrate how Javanese Muslim community, Ricklefts call it "mystic synthetics". According to Ricklefts, a Javanese Muslim must carry out the five pillars of the ritual. But also, they must accept the reality of the Javanese spiritual power, like believe in Ratu Kidul, Sunan Lawu or magical creature others.[6]

Javanese people are indeed identic with mystical beliefs. Therefore, Geertz classifies Javanese people as Javanese kejawen, Javanese priyayi and Javanese santri. Kejawen Islamic society is a syncretic Javanese society. Javanese priyayi are aristocratic Javanese groups and Javanese santri groups are adherents of pure Islamic teachings. According to Geertz, the Javanese people who belong to the Javanese group are the Yogyakarta community palace and rural communities.[7] Lamongan is one of the areas in Java that is mostly rural. as we know, there is one Wali Songo buried there, namely Sunan Drajat. One of the wali who spread Islam in the land of Java, especially in Lamongan. After the presence of Islam, many traditions have escaped the influence of Javanese mysticism. However, it does not mean that Javanese cultures are abandoned, including pepali nikah.

\section{The Prohibition Marriage in Islam}

According to Islamic sharia, the prohibition of marriage between man and woman is divided into two. First, the marriage ban forever (mahram muabbad) and the temporary marriage ban (ghoiru muabbad). Marriage ban forever agreed upon, that is nasab, semenda and sesusuan. there are seven types of women who should not be married because of nasab, 
that are a mother (including grandma according to the lineup), biological sister, mother's sister, father sister's, and the daughter of a brother (Quran an-Nisa 23).

There are eight temporary obstacles (mahram ghairu muabbad), that are married two sisters, the woman who has repudiated thrice, married to slaves, polygamy of more than four wives, marry someone else's wife, women in the iddah period, non-Muslim women, and during ihram period. Moreover, there are some types of marriage are prohibited, that are contract marriage (mut'ah marriage), syigor marriage, muhallil marriage, and interfaith marriages.[8]

Mohammad Azad classifies the nine reasons Muslims can't marry each other. First, prohibition due to Consangutinity of Blood Relationship (Tahrim-al-nasab): A Muslim is prohibited to marry His ascendants or descendants; His father's and mother's descendants; and the sisters or brothers of any ascendant.

Second, the prohibition on account of affinity (tahrim al-mushahirat). A Muslim violates the law if they are marriage ascendants or descendants of his wife, and the wife has any ascendants or descendant.

Third, the prohibition cause of fosterage (Riza). A child is called a "foster child" of a woman who is not the mother of the child and has been caring for a child in the meantime under two years. The woman is called "foster mother." Islamic law forbids marriage to some extent regarding foster care. A man might not marry, for example, marry him, foster mother or foster sister.

Fourth, prohibition on account of Unlawful Conjunction, that is the number of wives, Muslim men may not marry more than four women, but a Muslim woman can only marry one husband at the same time. And the relationship between co-wives: A man is forbidden to have two wives at the same time, which are interrelated by relatives, affinity or foster children. For example, a man may not marry two sisters at the same time or to marry his wife's sister during his wife's lifetime.

Fifth, prohibition during iddah period: A widow, divorced woman or woman who is pregnant by illicit relations is forbidden to remarry or remarry for some time iddah.

Sixth, prohibition because of divorce, It is not permissible for a man to marry an independent woman whom he has divorced three times, nor is a slave whom he has divorced twice, until another man has legally married her and the marriage has been effectively perfected with her and then he had divorced her or has died and thereafter her Iddat has ended.

Seventh, prohibition because of different religion, according to Hanafi school, a man may marry a muslim woman or a kitabiyah, but a muslim woman just can marry with Muslim.

The Maliki school of interfaith marriage law has two opinions, namely: first, marriage to kitabiyah is makruh, both dzimmiyah (non-Muslim women who are in regions or countries subject to Islamic law) and harbiyah, but makruh bigger. but if it is feared that this wife of our kitabiyah will influence her children and leave her father's religion, then the law is haram. Second, it is not makruh absolute because the verse of Quran does not prohibit absolutely. The Maliki school of thought methodology uses the approach of Sad al Zariah (blocking the path that leads to evil). If it is feared that ugliness will arise in interfaith marriages, then it is forbidden.

Likewise, the Shafi'i school of thought, also believes that it is permissible to marry a woman of the ahlul kitab, and who belongs to the group of ahlul kitab according to the Shafi'i school are Jewish and Christian women descendants of the people of the nation of Israel and do not include other nations, even including Jewish and Christian.

In the Hambali school of study of interfaith marriages, it is stated that it is forbidden to marry nonmuslim women, and may marry Jewish and Christian women. This group in 
connection with the issue of interfaith marriages supports the opinion of their teacher, Imam Shafi'i. But it does not limit that those who are included in the ahlul kitab are Jews and Christians from the Nation of Israel. Only, but stated that women who adhered to Jews and Christians since the time of the Prophet Muhammad had not been sent to be a prophet.

Eight, prohibition because of supervening illegality: If one party in a marriage becomes a worshiper of fire, or an idolater or husband becomes a Christian (apostate) then marriage is invalid by what is known as supervenient prohibition.

Ninth, Prohibition of Pilgrimage: A man who has gone to perform the pilgrimage (pilgrimage) and had entered the holy land of Kaba after wearing the hajj (ahram) dress, might not sign a marriage contract. This is off-limits to Muslim marriages and determines the legality of marriage.

\section{Pepali of Marriages (prohibition Marriage) in Modo Lamongan (East Java)}

Etymologically, pepali is a Sanskrit language which means discourse or message. in the Indonesian Javanese literary language, written by S. Butler Atmaja, it means avoidance or prohibition. According to Tardjan Hadidjaya, described by Petir Abimanyu, pepali is defined as a grip or way of life. According to Soetardi Soeryohoedoyo pepali is teaching, instruction, and rules.[9]

In terminology, pepali is the embodiment of values seen in every action or behavior of the members of the community, needs to be upheld for the rhythm of life following the power of nature and the noble ideals of the community or nation. The values contained in pepali can show identity and the personality of community groups and these are members of the community action guidelines. So, this norm is an action that reflects the value created as an example or next action. Pepali can be divided into two groups: first, pepali which generally can be applied to all citizens, not related to a group or community, region, ethnicity, nation or religion. Second, pepali is limited to groups, communities, regions, ethnicity, nation or religion only.

This research focuses on the discussion about Javanese marriage pepali in Modo, Lamongan East Java. So that it will only discuss the prohibitions or restrictions on marriage that apply to Javanese people, especially rural communities in Modo, Lamongan, East Java before carrying out the marriage contract and procession. Lamongan, is one of the places where the tradition pepali nikah is still preserved until today. From the perspective of the Sociology of Law, customs should have its purpose and objectives. There must be philosophical meaning in them, which is the focus of this research. However, this micro research can be a general description of the Javanese community as a whole, both in East Java, Central Java and West Java.

Javanese indigenous people, like other traditional societies in the world, are people who like the mystical system. Like Malays nation. although Malays in general are strict Muslims, they have never adopted the whole of Islamic law, and Muslim law applied in Malays is Muslim law which varies according to Malay custom.[10]

Some customary law in Malaysia even becomes a source of legal law. One of them, temenggong customs are identified with the Muslim system and absorbed by the Sultanate institutions. Indigenous temenggong countries became Muslim Sultanate countries. Later, the teachings of Islam were absorbed into the custom of the Temenggong and both become part of 
one system, despite customary traces. Temenggong can still be found, especially in Malay heritage.

Throughout the history of Javanese society, mysticism has colored customs, language, science and religion. The word mystic comes from the Greek mystics which means mystery or secret. The word myth means a story that has a historical background that is believed by the community as a story that happened, is considered sacred, contains many magical things, and generally played by gods.[11]

One of the classic Javanese mythologies says, wong Jawa iku nggoning semu, sinamun ing samudana, sesadone ingados manis, that means the Javanese are all mythologies, everything is disguised to look beautiful and sweet. Popping anger is obscene. The attitude of feeling is very important to protect the feelings of others.[12]

The fact needs to be recognized. In this research, many terms in the Javanese language are found which contain a certain meaning. Much strict advice is given in metaphorical sentences. this aims so that the speech is not interpreted as a form of anger and does not offend the speaker.

According to the authors, the Javanese public trust in marriage pepali can be grouped into two types. first mystic pepali marriage and second non-mystic pepali marriage. Mystic Pepali marriage is a marriage that is forbidden based on mystical beliefs. The pepali of this kind is born from the stories of the ancient past that are still believed by the Javanese people to this day. Whereas non-mystical pepali marriage is a marriage that is prohibited for social reasons such as maintaining peace and avoiding public ridicule.

Below are the types of Mystic Pepali marriage (mystic prohibition marriage).

\section{a. The Prohibition Marriage Because of Pasahtowan}

Pasahtowan is the union between the number of neptu (birthday) wife and future husband. Every day, month and year have different values. Sunday has a value of 5, Monday has a value 4, Tuesday has a value 3 , Wednesday has a value 7 , Thursday has a value 8 , Friday has a value 6 and Saturday has a value 9. Then, the pasaran in Java calender have different values too. Kliwon has a value 8. Legi has a value 5, Pahing has a value 9, Pon has a value 7 and Wage has a value 4.[13]

Calculation (neptu) in Javanese society is very important. Almost every act or intention must use calculations. All of these calculations are in the Javanese Primbon. In Javanese customs, the marriage calculation is introduced. These calculations illustrate or predict the prospect when wedding through the household.

How to calculate it by adding the birth of a neptu between future husband and wife, then divided by four. The rest of is used as a reference calculation. If the calculations are the remaining one, husband and wife who enter this category will will have difficulty getting offspring. If the calculations are the remaining two, husband and wife who enter this category will be many offspring. If the calculation of the remaining three, husband and wife who enter this category will get an abundant fortune. and if the calculation of the remaining four, one of the husband or wife will die. This provision is found in the Primbon Book of Javanese society.

For the example, there is a man was born on a Saturday (the value is 9) and Pahing (the value is 9) the amount is 18 , and there is a woman was born on Monday (the value is 4) and Legi (the value is 5) the amount is 9. Then the amount 18 from the count of man and 9 from the count of women is 27. So, 27 divided by 4 then the result is 6 and the rest are 1 . According to the Primbon, this couple will have difficulty getting offspring. 
Because of the importance of the count of weton, it is in the matchmaking and marriage of Java, especially those who still apply the count (pasahtowan) to Primbon, many marriages fail because of the mismatch of the neptu count of the bride and groom. They frustrate arranged marriages because they are counted as falling on bad or bad counts, which in the end their relationship is only a relationship between relatives and not husband and wife.

Semiyati the only one traditional figure in Modo Lamongan is a Muslim. Every day she worships like a muslim. According to Semiyati, uses pasahtowan to seek profit, happiness and permanence of the household. Every parent who will marry them child, usually come to Semiyati and asks to do the calculation of the birthday of their sons and daughters. According to her, although it is not taught in the religion of Islam, but the purpose of the pesahtowan tradition is good. Even though there were those who had arranged marriages, the community believed it was the best decision and accepted it sincerely. She usually gives advice before and after doing calculations the pasahtowan. If the results are not good, she asks that parents believe that the couple to be married is indeed not a match. The above shows that pepali has a place in the Javanese marriage procession to the present. Although modernization has developed, pepali is still used and not abandoned in Javanese premarital processions.

\section{b. The Prohibition Marriage Because of Home Position (lor-kulon position)}

Lor-kulon is a Javanese language which means lor (north) and kulon (west), meaning northwest direction. Javanese people do not allow someone to marry someone whose house is northwest of his house. northwest is interpreted as iron-fire.

This prohibition stems from the story of the attack on the kingdom of Lwaram, an ally of the Srivijaya kingdom against the Medangkemulan kingdom, which killed king Darmawangsa Teguh during his son's marriage to Prabu Airlangga. King Dharmawangsa Teguh was the last king of the Medang kingdom on Java.

In Modo the area in the direction of Lor-kulon is Rebuloh, Therefore, there is no one from the community there who married to someone who is from Rebuloh. According Semiyati, this tradition is maintained so that tragic events in the past are not repeated.

Below are the types of non-mystic Pepali marriage (non-mystic prohibition marriage). It is because this pepali emphasizes maintaining the value of harmony and family.

\section{c. The Prohibition Marriage Because of Pancer wali}

The pancer wali phenomenon occurs when a woman marries the son of her father's brother. The father's male family are people who can represent the bride's father as a marriage guardian. If the bride's father dies, the brother or uncle of the father's family must become the marriage guardian. That's why as a person who can be a guardian is not allowed to be in-laws.

\section{d. Prohibition Marriage Because of Sibling Relationship}

Javanese people do not allow marriage between brothers and sisters-in-law. for example, between sister-in-law and brother-in-law. This type of marriage is forbidden because it is feared that if a divorce occurs in one partner, it will cause damage to the harmony of the other couple and even damage harmony and cause hostility between families. 


\section{The Urgency of Pepali in Java Marriage Culture}

Javanese traditional ceremonies carried out in order to achieve inner peace of life, by carrying out traditional ceremonies, the Javanese fulfill their spiritual needs, "eling marang purwo duksino" Javanese spiritual life indeed originates from religion that is decorated with local culture, therefore the religious orientation of Javanese people always pay attention to the noble values that have been passed down from their ancestors.[14]

As mentioned earlier, rural Javanese people are kejawen people. Kejawen is seen as a science that has the main teachings, namely to build manners or rules in a good life. The Javanese are so great at paying attention to safety, that eventually they will be classified as lucky people. Luck is also marked by having good offspring in marriage. Therefore, in Javanese philosophy, banyu kuwi mili mudhun that mean -that parental disposition will decrease in children- it always gets emphasis. In other words, marriage is a period of preparation or laying the foundations of the family, so that it is always sought towards the perfection of life.

Pepali tradition has been strongly rooted among the people of a rural community in Modo, Lamongan. There are considerable meanings to be studied in this tradition.

According to the $\mathrm{KH}$ Abdul Ghofur, a religious figure in Modo, a Kyai from a salaf pesantren in Modo too, reject the pepali tradition. When he married his son, he did not aplied the pepali marriage tradition, but he considered rules of religion. It is a form of endeavor to get a good partner. In Islam also prescribed thus, may choose a partner to be married. But he knows that in addition to using kafaah, Javanese people also pay attention in terms of pepali marriage. Besides that, pepali marriage also fosters submissive, loyal and alert nature. the purpose of obedience is to foster a child's adherence to parental advice. For example, when a marriage is in conflict with pepali, parents usually cancel the wedding plan, this will certainly train the child's obedience towards parents. The purpose of this cancellation is not to hurt the child, but to choose the best match for him through customary procedures.

Then, the meaning of pepali is; First, pepali marriage is as parents' advice for their children who are getting married. Through pepali's advice, a child is expected to be careful in choosing a mate. So that the meaning contained in the implementation of the pepali above is a form of carefulness of the Javanese in choosing a mate. It is hoped that households that do not violate pepali can be happy and last a lifetime. Second, pepali aims to maintain harmony between families. Third, Avoiding pepali is not an absolute obligation, but implementing it is a form of respect for the ancestors and preservation of Javanese culture.

\section{The Harmonization of Pepali with Islamic Law Based of Them}

Law is a social phenomenon that changes depending on place and time. Sir Henry Maine said the law developed along with the development of society. From simple, traditional and tribal societies to complex and modern societies.[15] Law in the anthropological perspective is studied as an integral part of the culture as a whole. law is studied as a product of social interaction that is influenced by culture, politics, economics, ideology, religion, social structure and law as a social process that takes place in society. Even in fiqh rules, it says that changing the law is caused by changing time and place. This rule provides instructions that Islamic law can integrate with the environment and the circumstances that surround it. 
Anthropological law in the form of not merely tangible laws and regulations made by the state but also as local regulations that develop in the community (customary law/folk law) including regulatory mechanisms in society that function as social controls.

Customary law for the community functions as a balance sheet that can weigh good or bad levels, wrong or right, proper or inappropriate, appropriate or inappropriate, for an act or event in the community. So that the existence of customary law is more of a guideline to uphold and guarantee the maintenance of ethics of decency, discipline, morals and customary values in people's lives.

According to $\mathrm{KH}$ Abdul Ghofur, pepali is a tradition that has been maintained by Modo people from the past. maintaining the tradition is in the context of respecting ancestors. He said, this pepali could not be preserved and passed on to the next generation if it contained ugliness or danger. One of the reasons this tradition is still maintained is because it aims well to create a happy family. This goal same as a family goal in Islam, it's just a different way.

According to Siju, one of the Modo community said, she knew pepali in marriage, one of them was pasahtowan. when married 32 years ago, precisely in 1987 she used pepali. She claims to be lucky because she did not break the marriage papali. Then, Sutarji when he married his son, he asked traditional leaders to review pepali. This is done to follow the tradition. even 51 years ago when he married his wife, his parents did the same thing. Then, one of the people, Lasiyem, who breaking up pepali tradition revealed, pepali which she violated was pasahtowan. At that time the results of the calculations were 25 . according to traditional figures, the results were not good and it was predicted that one of them would be short-lived. But 36 years ago, Lasiyem still decided to hold a marriage even though it was opposed by her parents. After marriage, the marriage was harmonious and blessed with two sons. but in 2006 her husband died of titanus disease.

The term adat (Indonesia) is often translated as a custom. Customary meaning is not as simple as the original meaning taken from the word urf (Arabic). The universality of customary meaning can be divided into three aspects. first, adat can be interpreted as laws, rules, teachings, morality, agreements, actions following the rules of society. Secondly, adat is usually associated with customs that apply to certain regions. the three customs can be interpreted as a collection of literature produced by legal experts or illustrators.

A figh rule says al-adatu muhakkamah that means, the habit becomes law. this shows that Islamic law is flexible, not rigid, this could be one of the reasons in the Qur'an mentioned that Islam rahmatan lil alamin (Islam is a mercy for all nature). Like KH Abdul Ghafur said, that pepali still exist untin now, because pepali wants the goodness. Something good in the community must be maintained by the community.

Indonesia society is a religious society. Indonesia is not a country based on religion, but it cannot be denied that Indonesia is not a secular state that converts religion completely. Religion is a part of the Indonesian people's lives. therefore, in Indonesia, it does not explicitly apply Islamic Sharia, but it is intrinsic by applying the values of fundamental Islamic teachings. If we look at the pepali tradition singly, without seeing the reality of the people who practice it, then this tradition has directly deviated from the Islamic sharia guidance. in the tradition it is impressed, the custom has banned permitted marriages. wherein Islamic law, if a marriage meets the requirements and the legal basis of marriage and is not included in a marriage that is violated in Islam, then the marriage is valid.

Madhab scholars have agreed on the terms and conditions of marriage, despite differences of opinion. According to Hanafiyah scholars, the pillars of marriage are only ijab and qabul. Meanwhile, according to jumhur ulama, the pillars of marriage consist of agreement (ijab qabul), the existence of a prospective wife, the existence of a prospective husband, the 
existence of a guardian. The dowry and witnesses are a condition of marriage, but some fiqh scholars classify dowry and witnesses as the pillars of marriage. Sayyid Sabiq also concluded that the pillars of marriage also consisted of ijab and qabul, while others were included in the conditions.

Based on the requirements and pillars above, custom or tradition is not a consideration of marriage. But as discussed earlier, traditions in Indonesia, especially in Java, cannot simply be eliminated. especially with mystical traditions.

Legal decisions about muamalah (social/public) based on public benefit. the scholars have agreed that the purpose of law formation is a public benefit. then what if the legal considerations based on the benefit are contrary to the literal sound of the holy text, both the Qur'an and the hadith and with the consensus of the ulama (consensus).

Regarding this point, it is interesting to express Dr. Musthafa Syalabi in his book "Ta'lil al-Ahkam":

"If the benefit is contrary to the "text", in the field of mu'amalat and the customs (traditions) whose benefit has changed, then the benefit must be considered, and this cannot be said to be against the "text" through mere logical reasoning. On the contrary, it is precisely applying a lot of "texts" that indicate the necessity to maintain the benefit. However, if the benefit in the "text" does not change, then the text should not be ignored at all".

Syalabi said "Anyone who ponders deeply about the existence of the contradiction, it is only in its outward form. This is because the texts are revealed (created) to enforce certain benefits. When the problem has disappeared, then it is no longer relevant to be implemented. Similarly, if the text is accompanied by "illat" (logic of causality) it. When the illat disappears, the law is also finished. This is the understanding of the friends and the generations that follow.[16]

In the tradition of pepali nikah (prohibition of Javanese marriage) there are values of the purpose of Islamic marriage that the Javanese people want to realize. But the goal is realized with new rules, where the rules are made by humans themselves, rules made by the ancestors of the Javanese community.

Man-made law is considered a phenomenon that is subject to human needs and values (Oba, 2002). Likewise, with the tradition of Javanese pepali marriage, there are values that people want to achieve when implementing these traditions. Of the four pepali (prohibition of marriage) in Java, all of them have the goal to form a family that are sakinah mawaddah and rahmah, as mentioned in the Quran ar-Rum: 21:

And of His signs is this: He created for you helpmeets from yourselves that ye might find rest in them, and He ordained between you love and mercy. Lo! herein indeed are portents for folk who reflect.

Recognizing the tradition of pepali as a culture with Islamic nuances (or without), depends on how we see the ritual. In the perspective of Islam the pepali tradition is not the teachings of Islam. However, it is different if we look at the meaning behind the tradition, where there are values of Islamic teachings, one of which is in non-mystical pepali, the goal of Javanese society is to avoid fighting. they don't want to damage the neighbor relationship.

Moreover another value contained in the pepali tradition is the value of the caution of the Javanese community to decide on marriage. In Islam, the application of marriage rules, such as the pillars and conditions, kafaah (equality of faith) is a form of considerations for humans not to choose the wrong partner. Besides, Islam also does not forbid people to reject marriage 
proposals or cancel marriages. it's just that, sometimes the Javanese community rejects the proposal or cancels the marriage because of customary law and tradition.

Precisely for this reason, according to the author, Indonesian Jurisprudence should include customary law as a consideration in Indonesian marriage law. As is known, Indonesia is a country that consists of various tribes where each tribe has its customary law, especially related to customary marriage law.

According to the author, the idea to make customary law a consideration of national law is in line with the concept of Islam Nusantara in Indonesia. According to Quraish Syihab, apart from the pros and cons of Nusantara Islam, Quraish Shihab sees Islam Nusantara in terms of "substance", not form. If there is a form (culture) that is substantially following Islam it will be accepted, if contrary it will be rejected and revised. This is the principle of Islam in adapting to the culture. So, Islam can be various due to the diversity of the local culture. Even customs, habits and culture can be one source of the stipulation of Islamic law.

\section{Conclusion}

Pepali Marriage (Prohibition of Marriage) Javanese people are types of the prohibition of marriage based on Javanese society rules. Based on the nature of the marriage ban, it can be divided into two, first, the marriage ban is mystical, and the marriage ban is not mystical.

The urgency of pepali is; First, pepali marriage is as parents' advice for their children who are getting married. Through pepali's advice, a child is expected to be careful in choosing a mate. So that the meaning contained in the implementation of the pepali above is a form of carefulness of the Javanese in choosing a mate. It is hoped that households that do not violate pepali can be happy and last a lifetime. Second, pepali aims to maintain harmony between families. Third, Avoiding, pepali is not an absolute obligation, but implementing it is a form of respect for the ancestors and preservation of Javanese culture.

Explicitly pepali marriage (prohibition of marriage) as if Javanese society forbids the form of marriage allowed by Islam, but behind the ban, there is a hidden purpose, namely to create an eternal and happy family, following the purpose of Islamic marriage. pepali marriage philosophically holds the values of Islamic teachings. from this, it can be said that there is a harmonization between Islamic law and customary law although explicitly contradictory, both have the same objective.

This research also supports the opinion of Cliford Greetz who divides Javanese society into three types (abangan, santri, priyayi) the people in Jegreg Modo show this. Religious leaders there do not use pepali marriage but also do not forbid the community to practice it because it aims well for marriage.

Acknowledgements. This research supported by The Graduate School of Islamic Studies UIN Syarif Hidayatullah.

\section{References}

[1] T. O. Ihromi, Pokok-Pokok Antropologi Budaya. Jakarta: Yayasan Obor Indonesia, 2006.

[2] B. Herusatoto, Mitologi Jawa. Depok: Oncor Semesta Ilmu, 2012. 
[3] M. Azad dan S. Shajia Sharmin, "Laws of Muslim Marriage from the concept of the Holy Qur'an," International Journal of Engineering and Applied Sciences (IJEAS), 2018.

[4] S. Soekanto, Sosiologi Suatu Pengantar. Depok: Rajawali Press, 1987.

[5] I. Suny, "Kedudukan Hukum Islam dalam Sistem Ketatanegaraan Indonesia," dalam Hukum Islam di Indonesia; Perkembangan dan Pembentukan, Bandung: Remaja Rosdakarya, 1991.

[6] M. C. Ricklefts, Mengislamkan Jawa, Sejarah Islamisasi di Jawa dan Penentangnya dari 1930 Sampai Sekarang. Jakarta: Serambi Ilmu Semesta, 2013.

[7] C. Geertz, Abangan, Santri, Priyayi dalam Masyarakat Jawa. Jakarta: Dunia Pustaka Jaya, 1981.

[8] W. al-Zuhaily, Al-Fikih al Islami Waadillatuhu. Damsyiq: Daar al-Fikr, 1985.

[9] S. Soeryohoedoyo, Puncak-puncak dalam Pandangan Kesusilaan Kefilsafatan dan Ketuhanan dalam Kesusastraan. Jakarta: Citra Jaya, 1989.

[10] D. C. Buxbaum, "Islam and Customary Law in the Malaysian Legal Context," Springer Science Business Media Dordrecht, 1968.

[11] Hadiwijaya, Tokoh-tokoh Kejawen: Ajaran dan Pengaruhnya. Yogyakarta: Eule Book, 2010.

[12] Kodiran, Kebudayaan Jawa dalam Koentjaraningrat. Yogyakarta: Narasi, 1975.

[13] Gunasasmita, Kitab Primbon Jawa Serbaguna. Yogyakarta: Narasi, 2009.

[14] S. Endraswara, Falsafah Hidup Jawa: Menggali Mutiara Kebijakan dari Intisari Filsafah Kejawen. Yogyakarta: Cakrawala, 2012.

[15] S. H. Maine, A Study in Victorian Jurisprudencie. New York: Cambridge University Press, 2004.

[16] M. M. Syalabi, Ta'lil al-Ahkam. Beirut: Dar al-Nahdhah al-Arabiyyah, 1981. 